\section{TRACKING THE UNIVERSITY STUDENT SUCCESS: STATISTICAL QUALITY ASSESSMENT}

\begin{abstract}
Higher education institutions are continually striving to make education relevant to the working environment students will encounter upon graduation. One of the tools for enhancing an institution's quality and sufficiently informing students about their outcomes and learning opportunities is a quality assessment. Quality assessment is a long process which establishes measurable student learning outcomes, then analyses and interprets them. This enables students to receive feedback on their learning and helps them to improve their performance. The authors' objective was to gather empirical data on students' learning in order to improve the process of learning and to refine study programmes. A longitudinal study was used to observe students' performance and outcomes from entrance exams to state exams. Statistical analysis revealed that there is a correlation between the results of the admission tests and the study results, especially the connection between the results of the entrance test and the chance of successful completion of studies. No statistically significant correlation was found between the overall results of military students' studies. An interesting issue is a comparison between military and civilian students, as well as civilian students' results. As a continuous process, assessment of students' performance was observed up until the Final State Examination.
\end{abstract}

\section{KEYWORDS}

Statistical quality assessment, students' performance, quality assurance, learning outcomes, military and civilian students, higher education

\section{HOW TO CITE}

Čechová I., Neubauer J., Sedlačík M. (2019) 'Tracking the University Student Success: Statistical Quality Assessment', Journal on Efficiency and Responsibility in Education and Science, vol. 12, no. 1, pp. 12-25. http://dx.doi.org/10.7160/eriesj.2019.120102
Ivana Čechová ${ }^{1}$

Jirí Neubauer ${ }^{2}$

Marek Sedlačík ${ }^{2}$

${ }^{1}$ Language center, University of

Defence, Czech Republic

${ }^{2}$ Department of Quantitative

Methods, University of Defence,

Czech Republic

jiri.neubauer@unob.cz

Article history

Received

October 23, 2018

Received in revised form

January 31, 2019

Accepted

March 6, 2019

Available on-line

March 31, 2019

\title{
Highlights
}

- No statistically significant correlation was found between the overall results of entrance tests and the results in military students' studies.

- There is a significant difference in the entrance test results between successful and unsuccessful students.

- The entrance test results can help predict the probability of successful completion of studies.

\section{INTRODUCTION}

The term 'Education' derives from the Latin words 'Educere' (in English 'Educare'), which denotes the act of teaching, and 'Educatum' meaning to train or mould. As a general concept, it is not limited only to school-based teaching and learning processes, which are perceived as activities taking place in an educational environment and involving the learning of a subject.

In its broadest sense, education is the key to learning, understanding, and successfully meeting the challenges of the contemporary world. The importance of education in Europe has been endorsed at the highest level in the last decades. The European Union, and the Czech Republic as a member, pay constant attention to education in all its forms: formal, non-formal, and informal. According to strategic documents: 'Education and training systems must adapt to the new realities of the $21^{\text {st }}$ century. The European Union and its special commission for education work closely with particular policymakers to support the development of higher education policies in EU countries in line with the Education and Training 2020 strategy' (ET2020). The modernisation agenda link outside the EC domain for higher education fixes five key priorities for higher education in the EU:

- increasing the number of higher education graduates

- improving the quality and relevance of teaching and learning 
- $\quad$ promoting the mobility of students and staff and crossborder cooperation

- strengthening the "knowledge triangle", linking education, research, and innovation

- creating effective governance and funding mechanisms for higher education (ET 2020)

Politicians, stakeholders, teachers, and parents consider schools and universities to be a place where students are supposed to learn. Students themselves consider schools and universities to be a place where they are supposed to be taught. Kurtus (2012) defines the educational process as: 'a general process for providing education to students, such that they understand the information, are able to use or apply it and retain what they have learned'. For Peter Senge (1990), real learning gets to the heart of what it is to be human. We become able to re-create ourselves. This applies to both individuals and organizations.

The face of higher education has been changing rapidly, especially in recent decades. In her report, Knight (2006: 7) emphasizes: 'Higher education is subject to mounting pressures. It is expected, for example, to engage with the challenges of sustainable development and to accommodate itself to mounting demands for lifelong learning'. Cech, Chromy a Skupinova. (2015: 189) emphasize: 'Education has been crucial for successful career and life, for growth, careers, and jobs'.

Moreover, new trends and challenges posed by the growing commercialization of higher education require that increased attention be paid to such issues as the quality of higher education provision and the portability of higher education qualification. 'New providers, such as virtual universities, branch campuses in other countries and corporate universities, are creating a new paradigm of higher education largely as a response to new demand, but also as a way of taking advantage of technological developments' (Knight 2006: 12).

Concern over quality in higher education, or generally in education, is not a new phenomenon and occurs in strategic documents such as UNESCO and Bologna process, among others. Article 11(a) of the World Declaration of Higher Education (UNESCO, 1998) declares: 'Quality in higher education is a multidimensional concept, which should embrace all its functions, and activities: teaching and academic programmes, research and scholarship, staffing, students, buildings, facilities, equipment, services to the community and the academic environment'.

In Europe, ministers responsible for higher education created and adopted the standards for quality assurance. The European Association for Quality Assurance in Higher Education was established to represent quality assurance, promote European cooperation in the field of quality assurance in higher education, and disseminate information and expertise among its members and to stakeholders in order to develop and share good practice and foster the European dimension of quality assurance (The European Association for Quality Assurance in Higher Education, 2005). Quality assurance is emphasized in the Bologna Process materials and places great emphasis on strengthening quality assurance.

\section{QUALITY ASSESSMENT IN HIGHER EDUCATION}

Quality assessment of teaching and learning is one of the core values of modern higher education. It is difficult to articulate one definition of quality assessment as each individual has their own instinctive understanding of what it means. Liu (2016: 16) combines many authors' experience and research and claims 'Quality is a relative concept. It depends upon a "benchmark", and it means different things to different stakeholders, governments, employers, students, academics, society, and so on'. Quality, assessment, and their related concepts and goals have become increasingly prominent in almost all sectors of our lives. For students, quality of education is connected to the contribution to individual development and the preparation for a position in society. Academic workers are more likely to define quality as a good academic training based on good knowledge transfer, a good learning environment and a good relationship between teaching and research (Vroeijenstijn, 1995). Quality assessment is used for purposes of accountability and the improvement of teaching and learning. In addition, stakeholders such as employers and government funding councils rely on assessment to provide them with data which ensures the quality of provision and standards of education (Hinett and Knight, 1996).

Increased access to higher education has resulted in unprecedented growth in the number of students attending universities in the world, and the Czech Republic is no exception. The rapid expansion of higher education over the last decade in Europe has raised serious public concerns about the adequacy of existing institutions for sustaining academic quality and standards and has led to the initiation of quality assessment in a number of countries.

The concept of 'quality' has become an established topic, and the concept of quality assurance and quality enhancement are widely used in higher education institutions (Noha, 2015). Moreover, Noha claims that 'quality' was originally derived from industries and businesses, and its definition in an educational context should be different from its meaning in other areas. This is mainly because the education process is very complicated and includes many elements, such as students, instructors, administrators, curriculum, teaching and assessment methods, which work with each other in a complex manner (Noha, 2015).

Higher education providers emphasize service quality because of its strategic role in enhancing competitiveness, attracting new students and retaining existing students (Sultan and Wong, 2013). Many authors have studied the impact of quality assessment on universities and found that it relates to the characteristics of external quality assessment schemes and the national and institutional context of the evaluated universities, as well as their initiatives and responses (Haapakorpi, 2011; Malau-Aduli, Zimitat and Malau-Aduli, 2011). According to Liu (2016), the growth and diversification of higher education, along with associated changes in pedagogy, require higher education systems to surrender any idea of broad common standards of academic performance between institutions, and even between subjects within a single university. Students gain their degrees or credentials with widely varying levels of proficiency and at different levels of difficulty. The same 
qualifications have different values for students from different universities or departments. Consequently, quality assessment has been initiated as a way to regulate the quality of provisions in various higher education institutions, as well as to publish information about quality to stakeholders (Liu, 2016).

The successful mastery of academic content, once viewed entirely as the learners' responsibility, is considered as a shared responsibility between the student, the teacher, and the educational institution (college, university). At the individual student level, learning outcomes are used to express what learners are expected to achieve and how they are expected to demonstrate that achievement. Learning outcomes can be defined as student attainment due to engagement in a particular set of teaching and learning experiences (Tam, 2014).

Satisfaction with their university, but not their perceptions of themselves as university customers, is a predictor of educational involvement. Not surprisingly, students who were more involved in their education tended to be older, have higher grade point averages, and attend class more often. However, these students also felt more entitled to outcomes, although they did not differ in their perceptions of whether or not they were customers of the university (Finney, Gillespie and Finney, 2010). According to Sapri, Kaka and Finch (2009) students' satisfaction plays an important role in determining accuracy and authenticity. Barnett (2011) claims that the satisfaction of students is important, as it is the only performance indicator of service quality for service providers of higher education.

There are many approaches to explaining or predicting students' performance and assessing quality in education (Geiger and Cooper, 2010; Kappe and van der Flier, 2012; Shahiri, Husaina and Rashida, 2015; Okubo et al., 2017; Gerritsen-van Leeuwenkamp, Joosten-ten Brinke and Kester, 2017). Mohamadi uses an instrument-electronic writing forum to get data for both formative and summative assessment (Mohamadi, 2018, Mazouch et al., 2018). However, the authors decided on the observation of students' performance, from entrance tests to their final exams, at one faculty of the University of Defence.

Many studies in this area have been conducted to assess the relationship between secondary school final exams and students' future academic performance (Platt, Turocy and Mc Glumphy 2001; Wharrad, Chapple and Price, 2003). Some studies focus on the eligibility test scores and academic performance (McIntosh and Munk, 2007; Winter and Dodou, 2011) All these studies were conducted among medical students or related specializations, however, no studies focus on the military environment were found.

Some authors concentrate their attention on the relationship between entrance examination and university/college performance, for example, Ferguson, James and Madeley (2002). Rigney (2003) claims that students with higher scores in entrance exams performed better in their university studies. The Rignys' research and his outcomes became a source of inspiration of the authors' research.

In this article, the authors publish the results of their work on bachelor studies, which are three years in duration, and focus on a quantitative part of their research. The objective of this article is to find out whether the entrance examination is a prerequisite for the successful completion of studies at the university. First, studies at the Faculty of Military Leadership with a focus on bachelor study programmes and entrance exams is described. The authors then concentrate on methodology. In this section, they give details about data collection and statistical analysis of outcomes. Next section concentrates on the discussion, followed finally by the authors' conclusions.

\section{MATERIALS AND METHODS}

\section{Studies at the Faculty of Military Leadership}

The research was carried out at the Faculty of Military Leadership (FML), which is a part of the University of Defence (UoD). The UoD is a military tertiary institution intended to educate military professionals in line with Czech military forces' requirements and ensures the education of both Czech Army specialists and civilian students within accredited bachelor, master and doctoral study programmes. All these programmes have two basic forms of study - fulltime and combined, which are legalized by Act no. 111/1998 Coll., on universities $\S 44$. The UoD strives to accommodate the interests of military and civilian study candidates who wish to complement their existing education in accordance with the rising demands on qualifications and respond to the change of professional orientation or the needs of requalification. In doing this, the UoD is reflecting European and worldwide lifelong learning trends. Students of both categories are required to fulfil the same requirements, although students of the combined form must combine their studies with a regular job and everyday duties.

\section{Bachelor study programme at the Faculty of Military Leadership}

FML provides university education in a Bachelor's degree programme, Follow-up Master's degree programme, Continuous Master's degree programme, and $\mathrm{PhD}$ degree programme.

The Bachelor's degree programme, Economics and Management, focuses particularly on the study of theoretical subjects in the field of economics and management and their application in the specific area of security and state defence, including the peculiarities arising from the functioning of military organizations. The study programme is conceived as a professionally oriented study; therefore, the thematic blocks focusing on the practical application of the theoretical knowledge delivered to the students within the subjects of the curriculum play a significant role in the study programme.

The study is designed for both military and civilian students, both in full-time and combined form. The study programme for military students is focused on the basic managerial skills necessary for the command and other functions of units, for organizing structures of other players of the state security system, and for fulfilling tasks within the framework of the obligations arising from the membership of the Czech Republic in the EU and NATO. In completing the study programme, civilian students become competent in the operation of the basic management positions associated with securing state security, both in the public and private sectors. 
The Economics and Management study programme includes three fields of study - Economics of State Defence, Military Management, and Security Management. The professional orientation of the study required an increase in the study modules within the structure of the study programme. Students are enrolled in study modules, which creates more space not only for teaching specific subjects of study modules but also for more effective interconnection of more theoretically conceived subjects of programme and field curricula into the specifics of particular study modules. The study modules correspond to the professional requirements of personnel in individual specializations (professions) in the Czech Army or groups of professions in the non-military sector of the state security system.

\section{Entrance exams for the Faculty of Military Leadership}

Applicants for military full-time study programmes take the following tests as part of their entrance exam: Learning Potential Test (LPT) - written test; English language (ELT) written test; and Physical fitness (PF) - practical test. Applicants for the military part-time study programme and civilians (both full time and part time) take only the Learning Potential Test. The Learning Potential Test is divided into three sections; each section contains ten questions. The first section deals with numeric thoughts and logic, the second focuses on spatial imagination and abstract thinking, and the last concentrates on basic mathematical skills. The Learning Potential Test result is assessed between 0 to 60 points; the pass mark for this test is 30 .

The English Language Test examines reading comprehension, vocabulary and grammar. The minimal entrance level should be at least A2 according to the Common European Framework of Reference for Languages, or SLP 1 (Standardized Language Profile) according to NATO STANAG 6001. The English Language Test is assessed between 0 to 50 points; the pass mark for this test is 25 .

The applicant's physical fitness is verified in two disciplines: a twelve-minute run and sit-ups for one minute, the result of each discipline being rated between 0 and 50 points. If the candidate in one of the two disciplines scores 0 points, his total point score from the fitness score is 0 points.

The candidate can reach a maximum of 160 points in the admission test. To determine the ranking of candidates who have successfully passed the admission test conditions, the weighted average ranking achieved by the candidate in the various parts of the admission test is used. This weighted mean is calculated via the following equation:

$\underline{60 \times \text { rank in } P L T+50 \times \text { rank in ELT }+50 \times \text { rank in PF }}$ 160

The ranking of candidates, in the case of the same weighted average, is determined firstly by a higher point assessment of the Learning Potential Test, followed by a higher point assessment of the English Language test, and lastly a higher point assessment from the physical fitness test. At the same point, the test scores from the Learning Potential Test, the English Language Test, and the Physical Fitness check are placed in the same order. An applicant who has earned 0 points in any part of the admission test fails to comply with the admission procedure.

\section{SAMPLE DESIGN AND DATA COLLECTION}

Examining aspects of the wide range of issues related to the service of men and women in the Army of the Czech Republic has been the subject of many standard research activities in the past. Saliger (2017) claims that the education of military professionals is of crucial importance and suggests education activities for competency development of leaders at the middle level in the military school system. Ullrich, Pokorny and Ambrozova (2017) carried out research on skills and abilities necessary for military professionals to perform their activities and functions in challenging conditions in a military environment, especially at the University of Defence. The authors placed their emphasis on the bachelor study programme of the FML, and for three years observed all students involved in this programme.

The target population for this study were all students studying at the University of Defence within an accredited study programme for the Faculty of Military Leadership. The survey was conducted as a longitudinal study whose objective was to observe students' success as well as difficulties, to identify reasons for their failures, and to create conditions necessary for changes and the creation of a new study programme. The authors assumed that the results of the entrance examinations are a prerequisite for the successful completion of studies and determined the following hypotheses:

$\mathrm{H}_{1:}$ There is a correlation between the results of entrance exams and study results.

$\mathrm{H}_{1 \mathrm{a}}$ : There is a correlation between the results of LPT and study results.

$\mathrm{H}_{1 \mathrm{~b}}$ : There is a correlation between the results of ELT and study results.

$\mathrm{H}_{1 \mathrm{c}}$ : There is a correlation between the results of PF and study results.

$\mathrm{H}_{2}$ : The study results of military and civilian students are comparable.

$\mathrm{H}_{3}$ : According to the results of entrance exams, the probability of successful completion of studies can be predicted by the logistic or probit regression model.

$\mathrm{H}_{3 \mathrm{a}}$ : According to the results of LPT, the probability of successful completion of studies can be predicted.

$\mathrm{H}_{3 \mathrm{~b}}$ : According to the results of ELT, the probability of successful completion of studies can be predicted.

$\mathrm{H}_{3 \mathrm{c}}$ : According to the results of $\mathrm{PF}$, the probability of successful completion of studies can be predicted.

This part of the analysis focuses on students (military and civilian) who successfully finished their studies in 2016. We have data from 61 military and 59 civilian students of the bachelor degree at Faculty of Military Leadership, University of Defence in Brno, Czech Republic. The students began their study in autumn 2013 and finished in summer 2016. To describe their study path we have acquired the following data: entrance examination results (entrance examination for military students consists of the Learning Potential Test, English Language Test 
and the Physical Fitness Test; civilian students have to pass only the Learning Potential Test), the weighted average of grades for each term (three-year bachelor study comprises of 6 terms, we use coding: $\mathrm{A}=1, \mathrm{~B}=1.5, \mathrm{C}=2, \mathrm{D}=2.5, \mathrm{E}=3$ ),

\section{RESULTS}

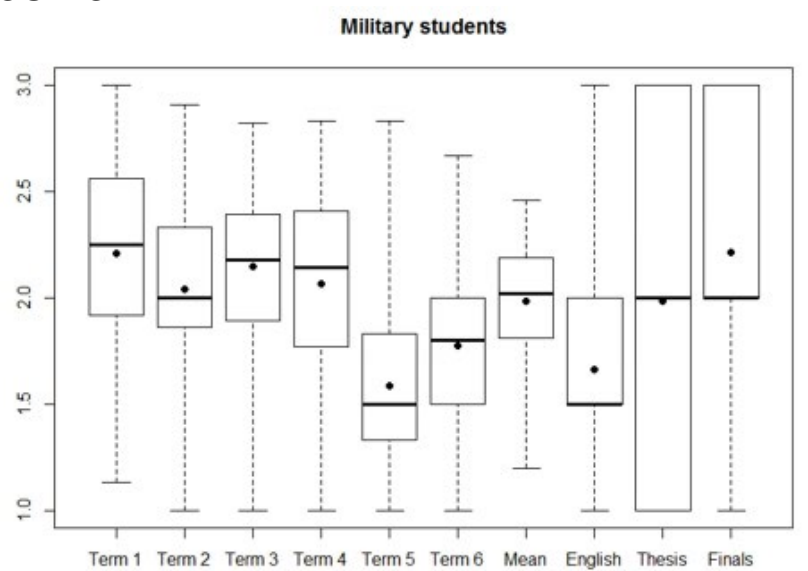

results of the final language test, the weighted mean for the whole study, results of bachelor thesis defense, and the finals (we use coding: excellent $=1$, very good $=2$, good $=3$, fail $=$ 4), see Figure 1.

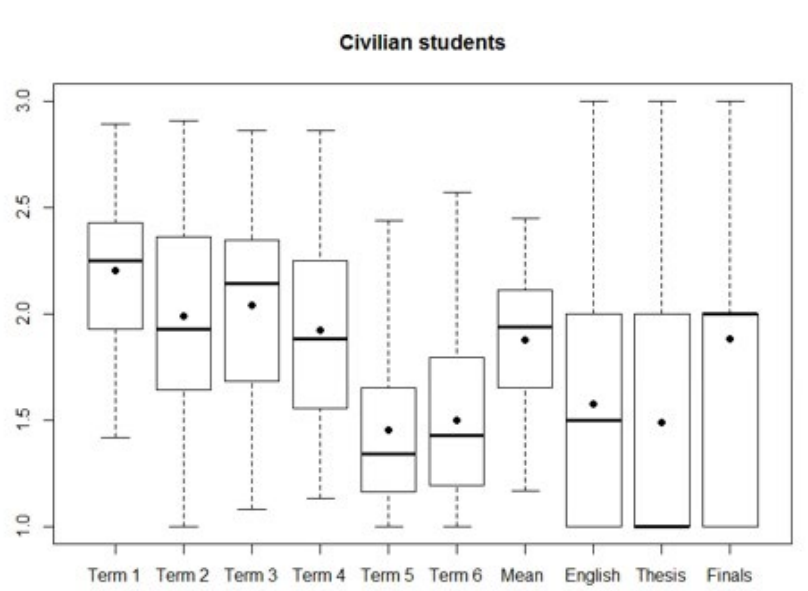

Figure 1: Boxplots of study results (military and civilian students); boxplots show the minimum, lower quartile, median, arithmetic mean (points), upper quartile and maximum

The results of LPT are on a scale from 0 to 60 , results of ELT and PF tests are on a scale from 0 to 50. The scales were unified for reasons of comparison (from 0 to 100). A significant

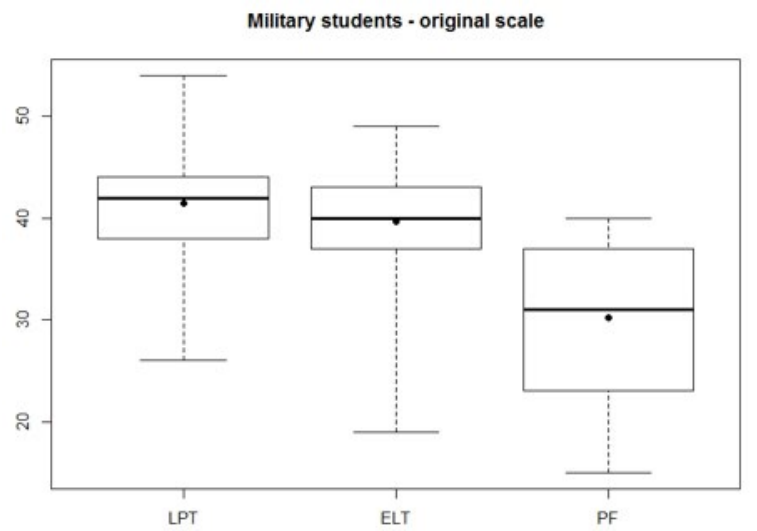

difference can be found between each part of the entrance test (Figure 2 and 3).

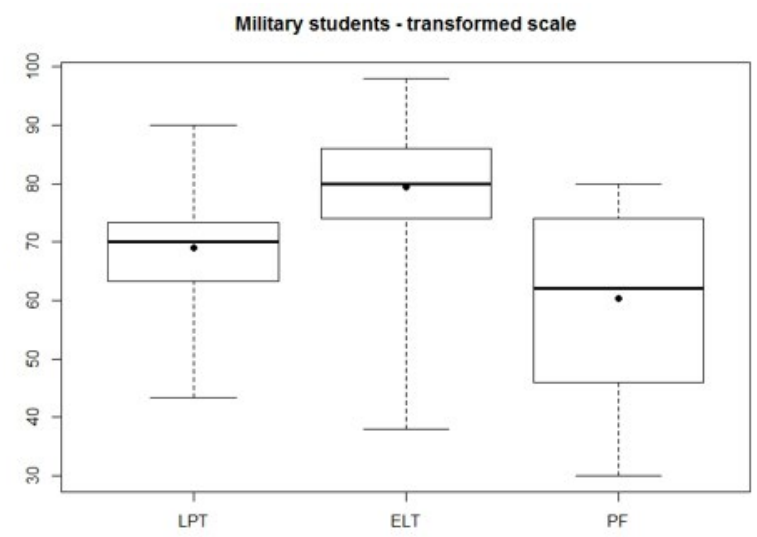

Figure 2: Boxplots of entrance test results of military students (original and transformed scale); boxplots show the minimum, lower quartile, median, arithmetic mean (points), upper quartile and maximum

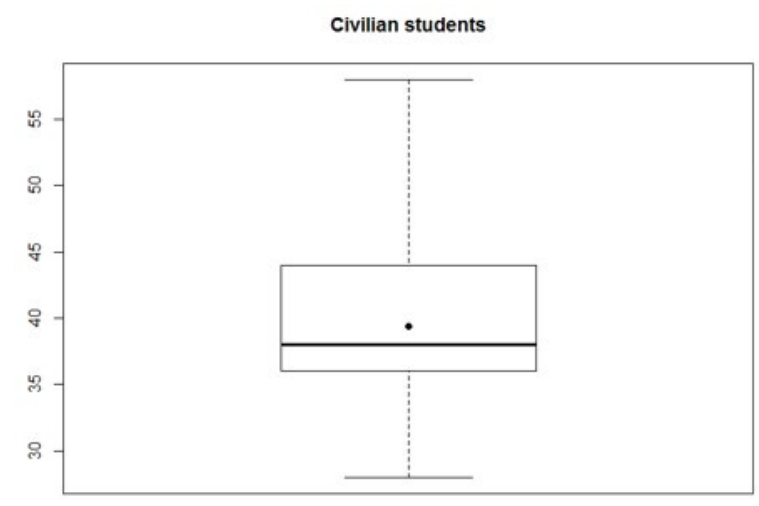

LPT

Figure 3: Boxplot of entrance test results of civilian students; boxplots show the minimum, lower quartile, median, arithmetic mean (points), upper quartile and maximum 
Table 1 and Table 2 contain pairwise correlations between the students' entrance exam results and study results (Pearson's and Spearman's correlation coefficients and tests of their statistical significance). Our aim is to check a possible positive or negative effect of the entrance exam results on study evaluation. The individual parts of the entrance test are not significantly correlated. The correlation coefficients are mostly negative; if we look at the statistically significant values (see Table 1 and Table 2), all coefficients are negative. The statistically significant correlations at the significance level 0.05 are highlighted in bold, those at the significance level 0.10 are in italics. It should be noted that the better the result achieved in the entrance exam, the higher the point evaluation, but in terms of grades it is reversed (the lower the number of the grade the better). The results in Table 1 show that the correlation between the study results for the military students and the results in the entrance exams are significant mainly for the ELT, not for LPT and PF tests. It can be deduced that the significant correlation for the study results and the overall results is predominantly caused by the correlation with the language test. On the other hand, the study results of civilian students are correlated with the LPT test (see Table 2).

We applied the correlation coefficient significance test in order to determine the correctness of the $\mathrm{H}_{1}$ hypothesis. The null hypothesis of this test claims that there is no correlation between analysed variables. This hypothesis is rejected mainly in case of study results and ELT test. According to this finding, we can say that hypothesis $\mathrm{H}_{1}$ is valid partly only. There is a correlation between ELT tests and study results, however, there is no relationship between both LPT and PF tests.

\begin{tabular}{|c|c|c|c|c|c|c|c|c|}
\hline & \multicolumn{4}{|c|}{ Overall entrance exam results } & \multicolumn{4}{|c|}{ LPT } \\
\hline & Pearson & $p$-value & Spearman & $p$-value & Pearson & $p$-value & Spearman & $p$-value \\
\hline Term 1 & -0.249 & 0.053 & -0.217 & 0.093 & -0.178 & 0.170 & -0.254 & 0.048 \\
\hline Term 2 & -0.178 & 0.170 & -0.098 & 0.455 & -0.063 & 0.630 & -0.063 & 0.628 \\
\hline Term 3 & -0.252 & 0.050 & -0.183 & 0.157 & -0.127 & 0.331 & -0.142 & 0.277 \\
\hline Term 4 & -0.204 & 0.114 & -0.194 & 0.133 & -0.252 & 0.050 & -0.313 & 0.014 \\
\hline Term 5 & -0.234 & 0.070 & -0.259 & 0.044 & -0.077 & 0.555 & -0.128 & 0.324 \\
\hline Term 6 & -0.046 & 0.727 & 0.025 & 0.847 & 0.086 & 0.512 & 0.083 & 0.524 \\
\hline Mean & -0.271 & 0.035 & -0.203 & 0.117 & -0.145 & 0.264 & -0.173 & 0.181 \\
\hline English & -0.244 & 0.058 & -0.274 & 0.033 & -0.212 & 0.100 & -0.188 & 0.147 \\
\hline Thesis & 0.035 & 0.787 & 0.049 & 0.705 & 0.087 & 0.503 & 0.057 & 0.664 \\
\hline \multirow[t]{3}{*}{ Finals } & 0.094 & 0.472 & 0.101 & 0.439 & -0.033 & 0.803 & -0.050 & 0.704 \\
\hline & \multicolumn{4}{|c|}{ ELT } & \multicolumn{4}{|c|}{ PF } \\
\hline & Pearson & $p$-value & Spearman & $p$-value & Pearson & $p$-value & Spearman & $p$-value \\
\hline Term 1 & -0.246 & 0.055 & -0.224 & 0.082 & -0.001 & 0.997 & -0.002 & 0.990 \\
\hline Term 2 & -0.350 & 0.006 & -0.256 & 0.046 & 0.089 & 0.493 & 0.129 & 0.320 \\
\hline Term 3 & -0.462 & 0.000 & -0.389 & 0.002 & 0.131 & 0.314 & 0.172 & 0.185 \\
\hline Term 4 & -0.289 & 0.024 & -0.310 & 0.015 & 0.156 & 0.230 & 0.186 & 0.152 \\
\hline Term 5 & -0.355 & 0.005 & -0.392 & 0.002 & 0.041 & 0.753 & 0.016 & 0.905 \\
\hline Term 6 & -0.181 & 0.164 & -0.253 & 0.049 & 0.021 & 0.874 & 0.016 & 0.902 \\
\hline Mean & -0.428 & 0.001 & -0.394 & 0.002 & 0.095 & 0.465 & 0.126 & 0.335 \\
\hline English & -0.316 & 0.013 & -0.369 & 0.003 & 0.097 & 0.459 & 0.075 & 0.566 \\
\hline Thesis & -0.282 & 0.028 & -0.239 & 0.063 & 0.206 & 0.111 & 0.221 & 0.087 \\
\hline Finals & -0.217 & 0.093 & -0.185 & 0.154 & 0.322 & 0.011 & 0.326 & 0.010 \\
\hline
\end{tabular}

Table 1: Correlation coefficients - military students; statistically significant correlations are emphasized (level $\alpha=0.05$ in bold, level $\alpha=0.10$ in italics) 


\begin{tabular}{l|cc|c|c} 
& \multicolumn{4}{|c}{ LPT } \\
& Pearson & $p$-value & Spearman & $p$-value \\
\hline Term 1 & -0.432 & $\mathbf{0 . 0 0 1}$ & -0.365 & $\mathbf{0 . 0 0 4}$ \\
\hline Term 2 & -0.330 & $\mathbf{0 . 0 1 1}$ & -0.275 & $\mathbf{0 . 0 3 5}$ \\
\hline Term 3 & -0.350 & $\mathbf{0 . 0 0 7}$ & -0.229 & 0.082 \\
\hline Term 4 & -0.218 & 0.097 & -0.200 & 0.130 \\
\hline Term 5 & -0.277 & $\mathbf{0 . 0 3 4}$ & -0.313 & $\mathbf{0 . 0 1 6}$ \\
\hline Term 6 & -0.235 & 0.073 & -0.141 & 0.286 \\
\hline Mean & -0.395 & $\mathbf{0 . 0 0 2}$ & -0.322 & $\mathbf{0 . 0 1 3}$ \\
\hline English & 0.058 & 0.661 & 0.111 & 0.404 \\
\hline Thesis & 0.003 & 0.979 & 0.097 & 0.465 \\
\hline Finals & -0.225 & 0.086 & -0.184 & 0.164 \\
\hline
\end{tabular}

and Runger, 2011). The $p$-values of the tests are $p=0.058$ and $p=0.032$, and we can say that military students are a little better according to the entrance test results (see Table 3).

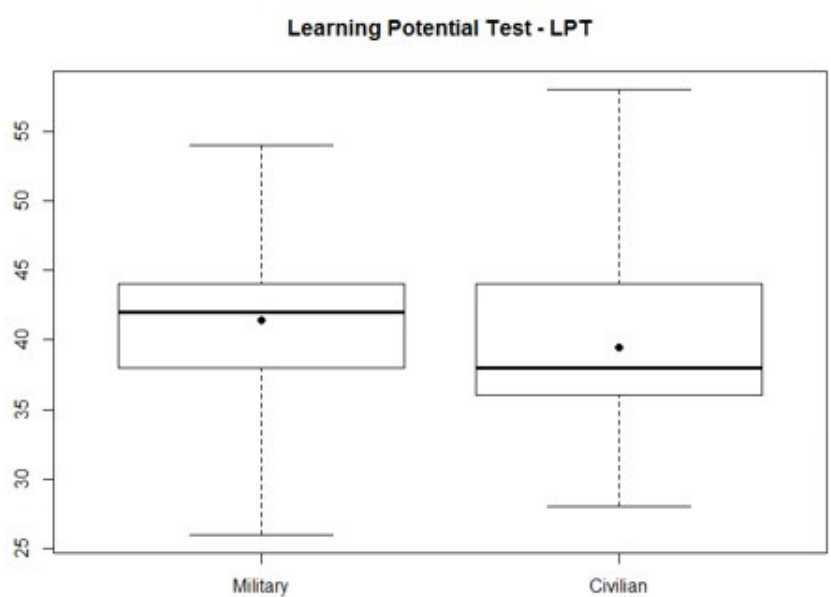

Table 2: Correlation coefficients - civilian students; statistically significant correlations are emphasized (level 0.05 in bold, level 0.10 in italics)

\section{Comparison of military and civilian studies}

Figure 4 contains boxplots of the LPT results for the military and civilian students. The mean for military students is 41.41 , the median is 42 and the standard deviation is 5.35 , while the mean for civilian students is 39.42 , the median is 38 and the standard deviation is 38 . We apply two sample t-test and two sample Wilcoxon test for comparison reasons (Montgomery

Figure 4: Results comparison of Learning Potential Test; boxplots show the minimum, lower quartile, median, arithmetic mean (points), upper quartile and maximum

Table 3 contains the results of the comparison between military and civilian students. Besides LPT, it summarizes comparisons of study achievements between analysed groups. In terms of the study results, civilian students perform better than military students. This can be confirmed by the Hotteling test, which is able to say that multivariate means of the analysed variables are significantly different $(p=0.006)$.

\begin{tabular}{|c|c|c|c|c|c|c|c|c|}
\hline & \multicolumn{2}{|c|}{ Military } & \multicolumn{2}{|c|}{ Civilian } & \multirow[b]{2}{*}{ t-test } & \multirow[b]{2}{*}{$p$-value } & \multirow[b]{2}{*}{ Wilcoxon test } & \multirow[b]{2}{*}{$p$-value } \\
\hline & Mean & Median & Mean & Median & & & & \\
\hline Test & 41.41 & 42.00 & 39.42 & 38.00 & 1.91 & 0.058 & 2,206 & 0.032 \\
\hline Term 1 & 2.21 & 2.25 & 2.20 & 2.25 & 0.06 & 0.955 & 1,867 & 0.725 \\
\hline Term 2 & 2.04 & 2.00 & 1.99 & 1.93 & 0.61 & 0.545 & 1,981 & 0.342 \\
\hline Term 3 & 2.15 & 2.18 & 2.04 & 2.14 & 1.38 & 0.169 & 1,983 & 0.337 \\
\hline Term 4 & 2.06 & 2.14 & 1.92 & 1.88 & 1.70 & 0.091 & 2,151 & 0.065 \\
\hline Term 5 & 1.59 & 1.50 & 1.45 & 1.34 & 1.89 & 0.061 & $2,240.5$ & 0.021 \\
\hline Term 6 & 1.78 & 1.80 & 1.50 & 1.43 & 4.18 & 0.000 & $2,551.5$ & 0.000 \\
\hline Mean & 1.98 & 2.02 & 1.88 & 1.94 & 1.89 & 0.061 & $2,168.5$ & 0.053 \\
\hline English & 1.66 & 1.50 & 1.58 & 1.50 & 0.91 & 0.364 & 1,974 & 0.339 \\
\hline Thesis & 1.98 & 2.00 & 1.49 & 1.00 & 3.94 & 0.000 & $2,431.5$ & 0.000 \\
\hline Finals & 2.21 & 2.00 & 1.88 & 2.00 & 2.32 & 0.022 & 2,211 & 0.022 \\
\hline
\end{tabular}

Table 3: Military and civilian students' comparison; statistically significant differences are emphasized (level $\alpha=0.05$ in bold, level $\alpha=0.10$ in italics)

Hypothesis $\mathrm{H}_{2}$ was rejected. Despite the fact that military students' results in the LPT test were better than the results of civilian students, in the second part of their study civilian students achieve better learning outcomes than military students.
The next aim of our analysis deals with the comparison of entrance exams for all applicants who successfully passed the entrance exam, students who successfully finished their studies, and students who began but did not finish their studies at the faculty. The analysis is performed separately for military and 
civilian students. We start with military students. The number of applicants who successfully passed the entrance exam was 168 , the number of students who successfully completed their studies was 61, and the number of unsuccessful students was 59. The means and the medians of the analysed groups are summarized in Table 4. Using the pairwise comparison (two sample t-test and Wilcoxon test) and Tukey method we determine a statistically significant difference between the groups (see Table 5). We concluded that the results of LPT significantly differ within the analysed groups. There are no significant differences in ELT and PF tests. It can be deduced that differences in overall results are caused by the results of the Learning Potential Test.

\begin{tabular}{|c|c|c|c|c|c|c|}
\hline \multirow{2}{*}{ Test } & \multicolumn{3}{|c|}{ Mean } & \multicolumn{3}{|c|}{ Median } \\
\hline & Accepted & Successful & Unsuccessful & Accepted & Successful & Unsuccessful \\
\hline LPT & 39.38 & 41.41 & 37.97 & 40 & 42 & 38 \\
\hline ELT & 39.53 & 39.67 & 39.14 & 40 & 40 & 40 \\
\hline PF & 28.82 & 30.16 & 28.15 & 28 & 31 & 28 \\
\hline Overall & 107.73 & 111.28 & 105.25 & 107 & 112 & 105 \\
\hline
\end{tabular}

Table 4: Military students - Means and medians of tests results according to the following groups; Accepted (applicants successfully passed the entrance exam), Successful (students successfully finished their studies) and Unsuccessful (students began but did not finish their studies)

\begin{tabular}{|c|c|c|c|c|c|c|}
\hline & \multicolumn{3}{|c|}{ LPT } & \multicolumn{3}{|c|}{ ELT } \\
\hline & t-test & Wilcoxon & Tukey & t-test & Wilcoxon & Tukey \\
\hline Successful - Accepted & 0.013 & 0.011 & 0.030 & 0.862 & 0.692 & 0.984 \\
\hline Successful - Unsuccessful & 0.000 & 0.000 & 0.001 & 0.607 & 0.546 & 0.854 \\
\hline \multirow[t]{3}{*}{ Accepted - Unsuccessful } & 0.080 & 0.087 & 0.186 & 0.630 & 0.714 & 0.883 \\
\hline & \multicolumn{3}{|c|}{ PF } & \multicolumn{3}{|c|}{ Overall } \\
\hline & t-test & Wilcoxon & Tukey & t-test & Wilcoxon & Tukey \\
\hline Successful - Accepted & 0.218 & 0.225 & 0.434 & 0.021 & 0.014 & 0.047 \\
\hline Successful - Unsuccessful & 0.131 & 0.144 & 0.289 & 0.000 & 0.000 & 0.003 \\
\hline Accepted - Unsuccessful & 0.552 & 0.546 & 0.821 & 0.108 & 0.078 & 0.232 \\
\hline
\end{tabular}

Table 5: Military students - Comparison of test for all applicants who successfully passed the entrance exam (Accepted), students successfully finished their studies (Successful), and students who began but did not finish their studies (Unsuccessful); $p$-values of two sample t-test, Wilcoxon test and Tukey multiple comparison; statistically significant differences are emphasized (level $\alpha=0.05$ in bold, level $\alpha=0.10$ in italics)

\begin{tabular}{|c|c|c|c|c|c|c|}
\hline \multirow{2}{*}{ Test } & \multicolumn{3}{|c|}{ Mean } & \multicolumn{3}{|c|}{ Median } \\
\hline & Accepted & Successful & Unsuccessful & Accepted & Successful & Unsuccessful \\
\hline LPT & 37.14 & 39.42 & 36.03 & 36 & 3 & 3( \\
\hline
\end{tabular}

Table 6: Civilian students - Means and medians of tests results according to the following groups; Accepted (applicants successfully passed the entrance exam), Successful (students successfully finished their studies) and Unsuccessful (students began but did not finish their studies) 
LPT - military students

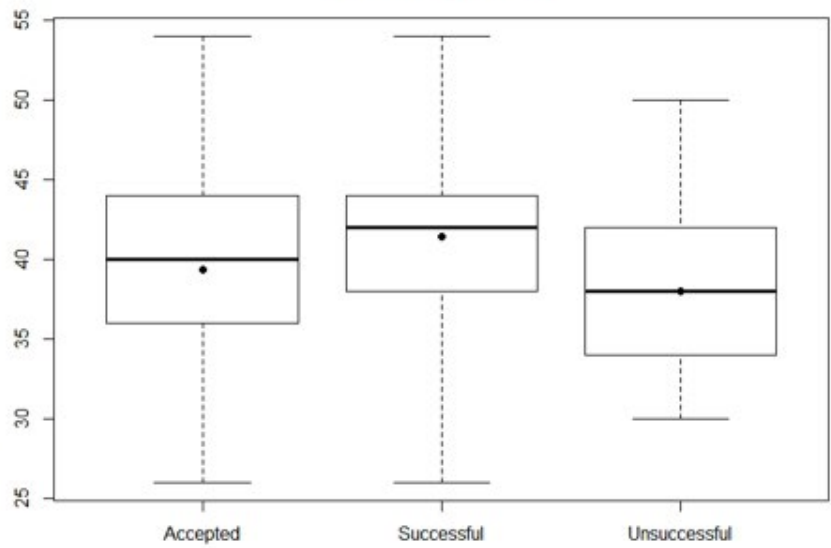

PF - military students

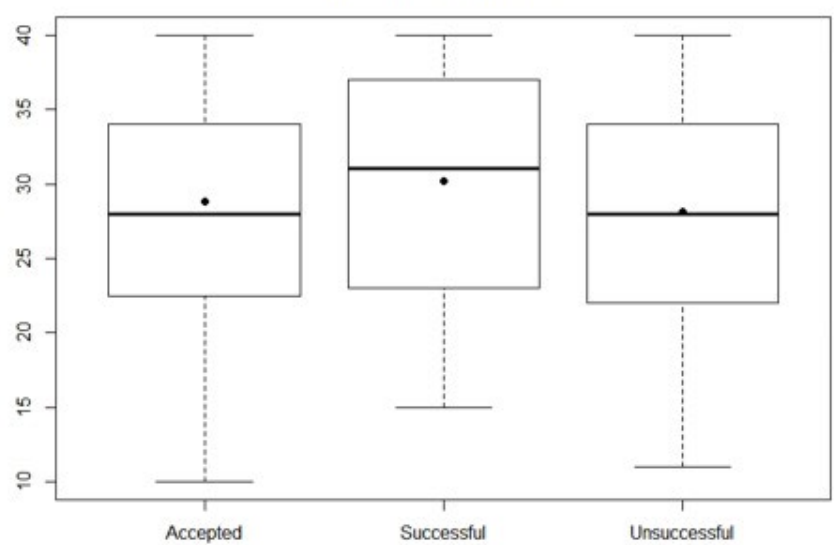

ELT - military students

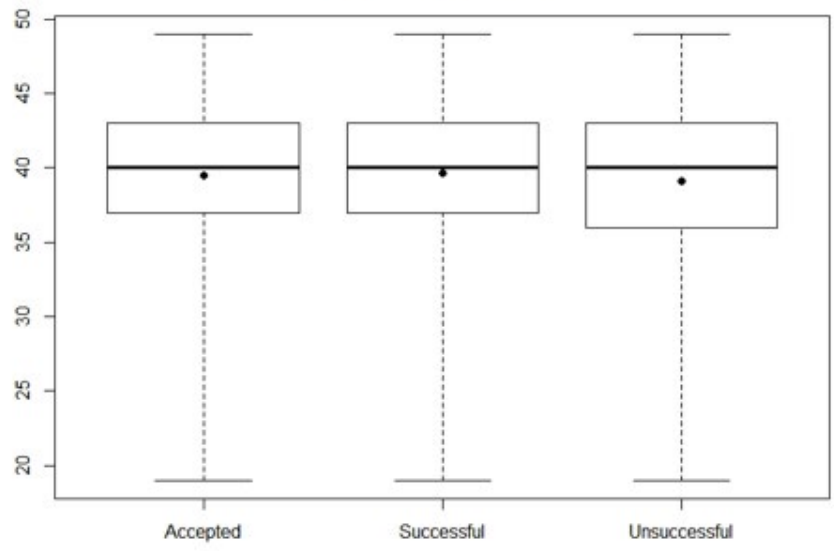

Overall test - military students

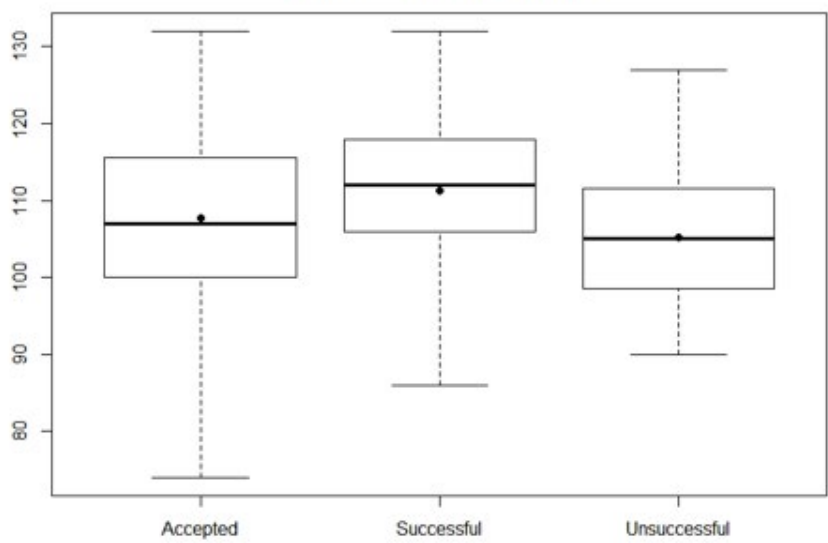

Figure 5: Tests comparison for all military applicants who successfully passed the entrance exam (Accepted), students who successfully finished their studies (Successful) and students who began but did not finish their studies (Unsuccessful); boxplots show the minimum, lower quartile, median, arithmetic mean (points), upper quartile and maximum

Similar methods were applied to data of civilian applicants and students. Civilian applicants were required to pass only the study aptitude test. The number of applicants who successfully passed the entrance exam was 273 , the number of students who successfully finished their studies was 59 , and the number of unsuccessful students was 63. Table 6 and Table 7 contain results which indicate that one can expect differences in test performance for the groups in question. It can be seen that there is a statistically significant difference between the results obtained in the study aptitude test for students who successfully finished their studies and unsuccessful students. Students who graduated achieved higher scores in the study aptitude test than students who had to terminate their studies.

\begin{tabular}{l|c|c|c} 
& \multicolumn{3}{|c}{ LPT } \\
& t-test & Wilcoxon & Tukey \\
\hline Successful - Accepted & $\mathbf{0 . 0 1 1}$ & $\mathbf{0 . 0 0 5}$ & $\mathbf{0 . 0 2 1}$ \\
\hline Successful - Unsuccessful & $\mathbf{0 . 0 0 0}$ & $\mathbf{0 . 0 0 1}$ & $\mathbf{0 . 0 0 5}$ \\
\hline Accepted - Unsuccessful & $\mathbf{0 . 0 8 1}$ & 0.383 & 0.375 \\
\hline
\end{tabular}

Table 7: Civilian students - Comparison of test for all applicants who successfully passed the entrance exam (Accepted), students who successfully finished their studies (Successful) and students who began but did not finish their studies (Unsuccessful); $p$-values of two sample t-test, Wilcoxon test and Tukey multiple comparison; statistically significant differences are emphasized (level $\alpha=0.05$ in bold, level $\alpha=0.10$ in italics) 


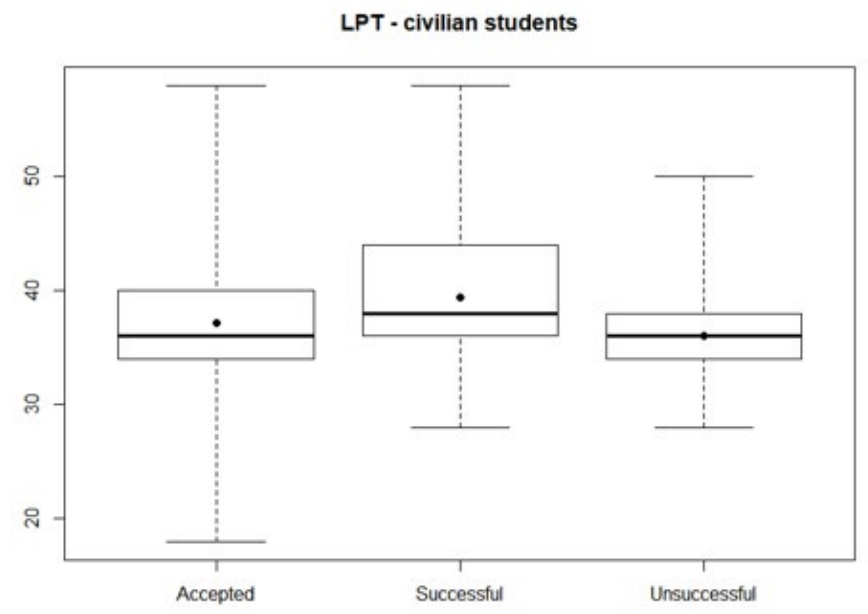

Figure 6: Test comparison for all civilian applicants who successfully passed the entrance exam (Accepted), students who successfully finished their studies (Successful) and students who began but did not finish their studies (Unsuccessful); boxplots show the minimum, lower quartile, median, arithmetic mean (points), upper quartile and maximum

As the last step, we would like to answer the question of whether the results in the entrance exam are somehow linked to overall study success. We focus now on the students who began to study and were able or not to finish their studies at the faculty. Firstly, we start with military students, then run the same procedure with civilian students, and finally put all the students together. The aim is to predict the probability of successful graduation as a function of the entrance exam results. For this purpose, we use logit and probit analysis (Dobson, 2002). The model for the logistic regression is given by the formula:

$$
\log \left(\frac{\pi_{i}}{1-\pi_{i}}\right)=\beta_{0}+\beta_{1} x_{i},
$$

then the probability $\pi_{i}^{\text {logit }}$ is according to formula (3):

$$
\pi_{i}^{\text {logit }}=\frac{\exp \left\{\beta_{0}+\beta_{1} x_{i}\right\}}{1-\exp \left\{\beta_{0}+\beta_{1} x_{i}\right\}} .
$$

The model for probit regression is according to formula (4):

$$
\Phi^{-1}\left(\pi_{i}\right)=\beta_{0}+\beta_{1} x_{i},
$$

the probability $\pi_{i}^{\text {probit }}$ is according to formula (5):

$$
\pi_{i}^{\text {probit }}=\Phi\left(\beta_{0}+\beta_{1} x_{i}\right)
$$

where $\Phi$ is the cumulative distribution function of standardized normal distribution $N(0,1)$.

We use a statistical software $\mathrm{R}$ (generalized linear model function $\mathrm{glm}$ ) to get the probability estimates.

Both military and civilian students had to pass the study aptitude test. Before calculation it is reasonable to split the range of possible outcomes into intervals $(25-30],(31-35], \ldots$, (55-60]. The ratio of successful students was computed for each interval. The results are shown in Table 8 and Figure 7.

\section{Military students}

\begin{tabular}{c|c|c|c|c|c|c|c|c|c}
\hline LOGIT & Estimate & Std. Error & $z$ value & $p$-value & PROBIT & Estimate & Std. Error & $z$ value & $p$-value \\
\hline$\beta_{0}$ & -4.92139 & 1.48570 & -3.313 & 0.00093 & $\beta_{0}$ & -3.03332 & 0.88148 & -3.441 & 0.00058 \\
\hline$\beta_{1}$ & 0.12642 & 0.03766 & 3.357 & 0.00079 & $\beta_{1}$ & 0.07794 & 0.02230 & 3.494 & 0.00048 \\
\hline
\end{tabular}

\section{Civilian students}

\begin{tabular}{c|c|c|c|c|c|c|c|c|c} 
LOGIT & Estimate & Std. Error & $z$ value & $p$-value & PROBIT & Estimate & Std. Error & $z$ value & $p$-value \\
\hline$\beta_{0}$ & -4.93215 & 1.48094 & -3.330 & 0.00087 & $\beta_{0}$ & -3.01491 & 0.87029 & -3.464 & 0.00053 \\
\hline$\beta_{1}$ & 0.13177 & 0.03985 & 3.307 & 0.00094 & $\beta_{1}$ & 0.08065 & 0.02340 & 3.447 & 0.00057 \\
\hline
\end{tabular}

\section{All students}

\begin{tabular}{c|c|c|c|c|c|c|c|c|c}
\hline LOGIT & Estimate & Std. Error & $z$ value & $p$-value & PROBIT & Estimate & Std. Error & $z$ value & $p$-value \\
\hline$\beta_{0}$ & -4.77392 & 1.02001 & -4.680 & 0.00000 & $\beta_{0}$ & -2.92726 & 0.60288 & -4.855 & 0.00000 \\
\hline$\beta_{1}$ & 0.12502 & 0.02662 & 4.696 & 0.00000 & $\beta_{1}$ & 0.07671 & 0.01571 & 4.882 & 0.00000 \\
\hline
\end{tabular}

Table 8: Logit and probit analysis, estimation results

Using logit analysis according to formula (3), we get for the military students the probability estimates:

$$
\hat{\pi}_{i}^{\text {logit }}=\frac{\exp \left\{-4.921+0.126 x_{i}\right\}}{1-\exp \left\{-4.921+0.126 x_{i}\right\}} .
$$

According to formula (5), probit analysis offers the estimates:

$$
\hat{\pi}_{i}^{\text {probit }}=\Phi\left(-3.033+0.078 x_{i}\right) \text {. }
$$

The estimates for civilian students and for all students can be obtained by the analogy. The links between the result in the Learning Potential Test and the ratio of success are shown in Figure 7. In can be deduced from the computed estimates that there is no difference between logit and probit analysis results; moreover, the estimated models are similar for all three analysed groups.

The entrance exam for the military students also consists, in 
addition to LPT, of the language test ELT and PF test. Contrary to the LPT, we were not able to build any model which can describe the link between the test results and study success. It could be concluded that the Learning Potential Test result is a reasonable predictor of study success. According to our findings, a candidate for military study has a greater than 50\% probability of successful graduation if he or she has a LPT test score greater than 39, and for a civilian student a score of 37.
Hypothesis $\mathrm{H}_{3}$ is valid partly only. We can state that hypotheses $\mathrm{H}_{3 \mathrm{~b}}$ and $\mathrm{H}_{3 \mathrm{c}}$ are not correct, we were not able to build the logit nor probit regression model which could describe the link between the ELT nor PF entrance test results and the probability of successful completion of studies. It is possible to predict the probability of successful completion of studies according to LPT test only.
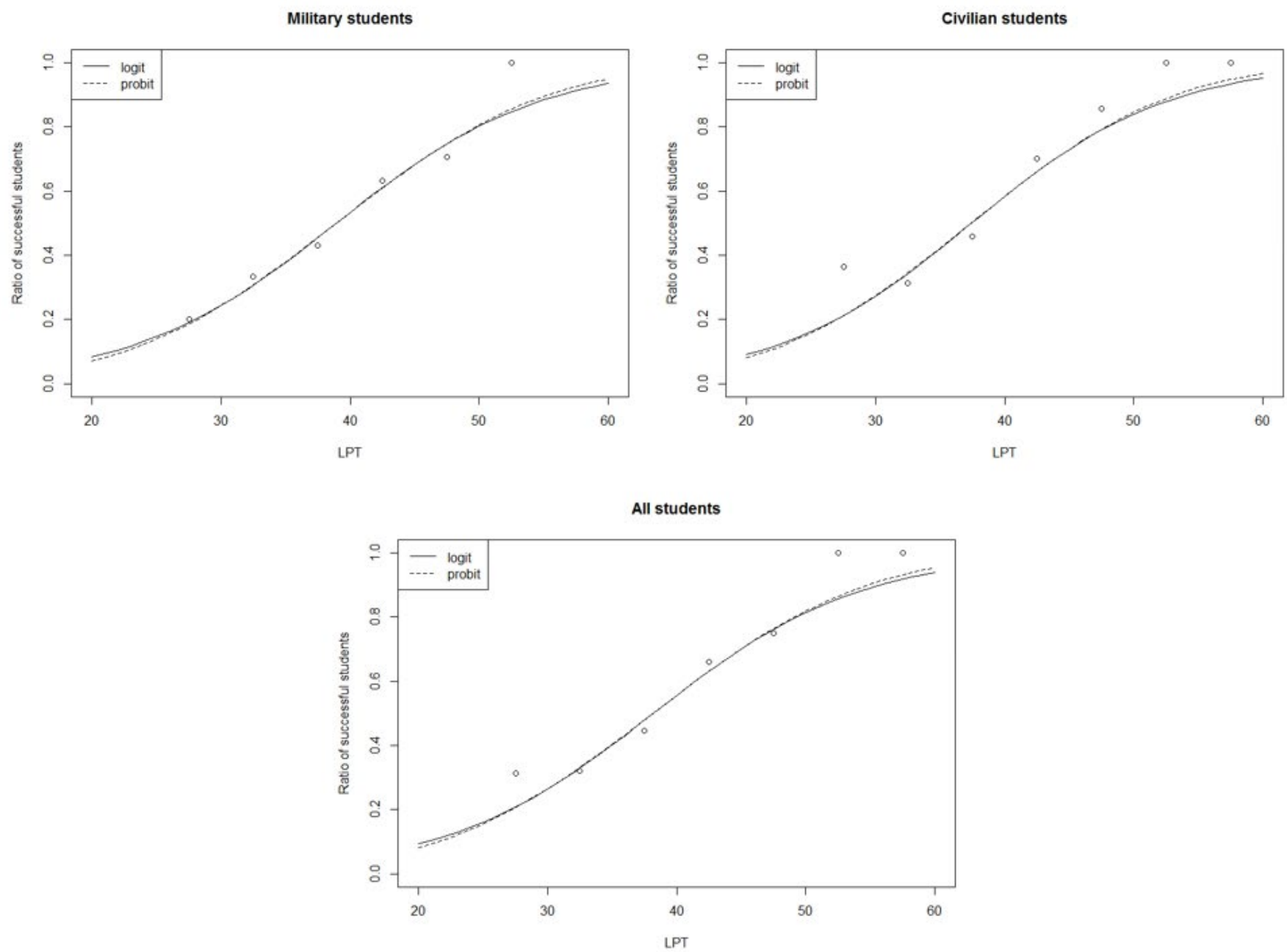

Figure 7: Logit and probit model of the ratio of successful study

\section{DISCUSSION}

There is substantial agreement that quality assessment is an effective technology for supporting a change in higher education institutions (Stensaker et al., 2006; Houston, 2010; Hazelkorn, 2011). In theory, quality assessment can provide the impetus for tertiary education/university change. There is no universal unified quality standard model that can be used to assess the quality criteria of tertiary education institutes.

Aboma (2009), in his research, focused on understanding academic success in higher institutions, prior academic achievement measures (preparatory school grade average point, aptitude test scores, and university entrance exam scores) and psychological variables (achievement motivation and academic self-efficacy) to predict first year university students' grade average point. The research outcomes prove that 'students' pre-college academic performances are strong predictors of grade average point at university level'. According to Aboma (2009), the better the pre-college academic performance, the better the study performance in the first grade at the university. Friedman and Mandel (2009) write about student retention and performance in higher education, which is an important issue for educators, students, and a nation facing critical professional labour shortages. In his work, he confirmed the hypothesis that Scholastic Aptitude test and High School Grade Point Average (HSGPA) scores would be positively related to academic performance and student retention.

The research on assessment in higher education gains increased attention abroad as well as at Czech universities, however, no studies in this area have focused on military environment.

The authors started their research in 2010, first concentrating 
on entrance exams. In their endeavour to widen understanding regarding factors predicting academic achievement in tertiary education, they compared entrance test results and tried to ascertain whether there is an independent relationship between success in the English Language Test and success in the Learning Potential Test. Their results prove the link between the Learning Potential Test and the English Language Test. If an applicant is good at English, he or she is also good at the Learning Potential Test (Sedlacik, Cechova and Doudova, 2013). They then focused on the item and test analysis of English Language Tests to ensure that entrance tests at the Faculty of Military leadership are reliable and fair. It was found that the established system of test design, moderation, pre-testing, item analysis, and the administration has become a viable and transparent way of selecting university candidates according to their knowledge level (Cechova, Neubauer and Sedlacik, 2014).

In this contribution, the authors decided to publish their statistical findings in order to find the correlation between entrance exams and students' success at their final exams. They focused on students (military and civilian) who successfully completed the bachelor degree at the Faculty of Military Leadership, University of Defence in Brno, Czech Republic. We can conclude that hypothesis $\mathrm{H}_{1}$ is valid partly only as there is the correlation between ELT test and study results. Correlation between LPT and PF tests was not significant. Hypothesis $\mathrm{H}_{2}$ was rejected as there are comparable results between military and civilian students till the half of their studies. Hypothesis $\mathrm{H}_{3}$ is valid partly only as only the LPT results can help predict the probability of successful completion of studies. Some outcomes were quite surprising and observation the students' success and especially difficulties helped create conditions for necessary changes in the creation of a new study programme. No statistically significant correlation was found between the overall result of entrance tests and the results in military students' studies:

1. there was no statistically significant correlation between the LPT test and study results;

2. there was no statistically significant correlation between the PF test and study results;

3. statistically significant correlation was found between the ELT test and the study results (the higher the number of points in the entrance test, the better the marks during the study).

Weak correlation binding the results of the LPT entrance tests to study results was indicated in civilian students' studies. There were significant correlations between the scores for the ELT and study results. Students who received high scores for the ELT in the entrance examination had a clear sense of purpose, and it influenced not only their English study but also their ability to learn special military knowledge, which is directly related to their future, skills required for international training, deployment in missions, and working in NATO structures. Furthermore, students are well informed about a fact that one of their duties during studies at the University of Defence is also to pass examination according to STANAG NATO 6001. Another interesting issue is the comparison between military and civilian students. It is possible to state that military students' results in the LPT test were better than the results of civilian students, and in the first half of the study the results of soldiers and civilians were comparable. However, in the second part of their study, it is possible to state that civilian students achieve better learning outcomes than military students. The explanation is based on a structure of military study programme. Military students after completing the 2nd semester of their study are enrolled in study modules according to their professional orientation. This guarantees their employment after graduation. Civilian students do not have any guarantee and only the best of them can find employment in the state service. This fact makes them achieve the best results.

The authors then concentrated on comparing the entrance test results of students who successfully finished their studies (Successful students) with those who failed (Unsuccessful students). Both groups, soldiers and civilian students, were compared. As expected, there are significant differences between Successful and Unsuccessful students, however, comparing ELT and PF tests results, no statistically significant differences were found.

When modelling the probability of successfully completing studies at the UoD, it was possible to build a model of logit and probit based only on the results of the LPT test. The parameters of these models are similar for both military and civilian students. Based on these models, it is possible to state that if a military student reaches more than 39 points in a LPT, the probability of successful completion of the study is more than $50 \%$; for civilians, the threshold is equal to 37 points.

\section{CONCLUSION}

A number of studies has examined the predictive validity of entrance tests with respect to study results but these studies were predominantly concentrated to the medical area. There is a lack in literature as well as research done with respect to military students and there is no comparable study in this area. At the University of Defence both military and civilian students study, which is not typical for military universities abroad and this fact makes possible to compare their results.

This research has brought interesting results which aid understanding of students' performance during their studies at the UoD, and which forms the basis for the development of new study programmes. The most surprising facts were the correlation between ELT tests and study results or difference between civilian and military students. The Faculty authorities were acquainted with this research results and knowledge of these outcomes was incorporated in the creation of a new study programme. The authors will strive to observe students' study results until completing their master degree and compare it with other programmes to find possible differences.

Another authors' endeavour is observing the students' performance from their first interest in studying at the UoD, from the preparatory course for admission to the UoD to their final state exam. The authors also hope that it will be possible to get outcomes from partnership military institutions to be able to compare universities of similar specialization. 
Aboma, O. (2009) 'Predicting First Year University Students' Academic Success', Electronic Journal of Research in Educational Psychology, Vol. 7, No. 3, pp. 1053-1072.

Act no. 111/1998 Coll., on universities $\S 44$ (1998) [online], Available: http://www.msmt.cz/vyzkum-a-vyvoj-2/zakon-c-111-1998-sb-ovysokych-skolach [20 Jan 2018].

Barnett, R. (2011) 'The marketised university: defending the indefensible', in Molesworth, M., Scullion, R. and Nixon, E. (Eds), The Marketisation of Higher Education and the Student as Consumer. Routledge, Oxon, pp. 39-52.

Cech, P., Chromy, J. and Skupinova, S. (2015) 'Company Training of Managers as a Part of the Human Resource Management in the Hotel Industry', in 2nd International Multidisciplinary Scientific Conference on Social Sciences and Arts (SGEM 2015), Psychology and Psychiatry, Sociology and Healthcare, Education, Vol. II, pp. 189-196.

Cechova, I., Neubauer, J. and Sedlacik, M. (2014) 'ComputerAdaptive Testing: Item Analysis and Statistics for Effective Testing', in Proceedings of the 13th European Conference on e-Learning ECEL-2014. Copenhagen, Denmark: Aalborg University Copenhagen, pp. 106-112.

Dobson, A.J. (2002) An Introduction to Generalized linear models. $2^{\text {nd }}$ ed. Chapman \& Hall/CRC.

Finney, T. Gillespie, R. and Finney, Z. (2010) 'Are students their universities' customers? An exploratory study', Education + Training, Vol. 52, No. 4, pp. 276-291. https://doi. org/10.1108/00400911011050954

Friedman, B. and Mandel, G.R. (2009) 'The Prediction of College Student Academic Performance and Retention: Application of Expectancy and Goal Setting Theories', Journal of College Student Retention Research Theory and Practice. Vol. 11, No. 2, pp. 227-246. https://doi.org/10.2190/CS.11.2.d

Geiger, M.A. and Cooper A.E. (2010) 'Predicting Academic Performance: The Impact of Expectancy and Needs Theory', The Journal of Experimental Education, Vol. 63, No. 3, pp. 251-262. https://doi.org/10.1080/00220973.1995.9943812

Gerritsen-van Leeuwenkamp, K. J., Joosten-ten Brinke D. and Kester L. (2017) 'Assessment quality in tertiary education: An integrative literature review', Studies in Educational Evaluation, Vol. 55, pp. 94-116. https://doi.org/10.1016/j.stueduc.2017.08.001

Haapakorpi, A. (2011) 'Quality assurance processes in Finnish universities: Direct and indirect outcomes and organisational conditions', Quality in Higher Education, Vol. 17, No. 1, pp. 69-81. https://doi.org/10.1080/13538322.2011.554311

Hazelkorn, E. (2011) Rankings and the reshaping of higher education. The battle for world-class excellence. Basingstoke: Palgrave Macmillan. https://doi.org/10.1057/9780230306394

Hinett, K. and Knight, P. (1996) 'Quality and assessment', Quality Assurance in Education, Vol. 4, No. 3, pp. 3-10. https://doi. org/10.1108/09684889610125832

Houston, D. (2010) 'Achievements and consequences of two decades of quality assurance in higher education: A personal view from the edge', Quality in Higher Education, Vol. 16, No. 2, pp. 177180. https://doi.org/10.1080/13538322.2010.485730

Kappe, R. and van der Flier, H. (2012) 'Predicting academic success in higher education: what's more important than being smart?', European Journal of Psychology of Education, Vol. 27, No. 4, pp. 605-619. https://doi.org/10.1007/s10212-011-0099-9
Knight, J. (2006) Higher Education Crossing Borders: A Guide to the Implications of the General Agreement on Trade in Services (GATS) for Cross-border Education. [online], Available: http://oasis.col.org/bitstream/handle/11599/208/GATS. pdf?sequence=1. [12 Jan 2017]

Kurtus, R. (2012) Tricks for Good Grades: Strategies to Succeed in School. SfC Publishing Co. Oregon, USA.

Liu, S. (2016) Quality Assurance and Institutional Transformation, Higher Education in Asia: Quality, Excellence and Governance. Springer Science+Business Media Singapore.

Malau-Aduli, B.S., Zimitat, C. and Malau-Aduli, A.O. (2011) 'Quality assured assessment processes: Evaluating staff response to change', Higher Education Management and Policy, Vol. 23, No. 1, pp. 1-24. https://doi.org/10.1787/hemp-23-5kgglbdlm4zw

Mazouch, P., Ptackova, V., Fischer, J. and Hulik, V. (2018) 'Students Who Have Unsuccessfully Studied in the Past - Analysis of Causes', Journal on Efficiency and Responsibility in Education and Science, Vol. 11, No. 3, pp. 66-72. https://doi.org/10.7160/ eriesj.2018.110303

McIntosh, J. and Munk, M.D. (2007) 'Scholastic ability vs family background in educational success: evidence from Danish sample survey data', Journal of Population Economics, Vol. 20, No. 1, pp. 101-120. https://doi.org/10.1007/s00148-006-0061-3

Mohamadi, Z. (2018) 'Comparative effect of online summative and formative assessment on EFL student writing ability', Studies in Educational Evaluation, Vol. 59, pp. 29-40. https://doi. org/10.1016/j.stueduc.2018.02.003

Montgomery, D.C. and Runger, G.C. (2011) Applied Statistics and Probability for Engineers. 5th ed. John Wiley \& Sons.

Noha, E. (2015) 'The concepts of quality, quality assurance and quality enhancement', Quality Assurance in Education, Vol. 23, No. 3, pp. 250-261. https://doi.org/10.1108/QAE-11-2012-0046

Okubo, K., Yamashita, T., Shimada, A. and Ogata, H. (2017) 'A neural network approach for students' performance prediction', in Proceedings of the Seventh International Learning Analytics \& Knowledge Conference. Canada, pp. 598-599. https://doi. org/10.1145/3027385.3029479

Platt, L., Turocy, P., and Mc Glumphy, B. (2001) 'Preadmission criteria as predictors of academic success in entry-level athletic training and other allied health educational programs', Journal of Athletic Training, Vol. 36, No. 2, pp 141-144.

Rigney T.J. (2003) 'Relationship between Admission Grades and Academic Achievement', The Irish Journal of Management, pp. $117-138$.

Saliger, R. (2017) 'Poznatky z výzkumu organizační kultury Armády České republiky - východisko $\mathrm{k}$ inovacím v edukaci leaderů ve vojenském školství’, in Vzděláváni dospělých 2016-východiska a inspirace pro teorii a praxi. Praha: Česká andragogická společnost, pp. 259-272.

Sapri, M., Kaka, A. and Finch, E. (2009) 'Factors that influence student's level of satisfaction with regards to higher educational facilities services', Malaysian Journal of Real Estate, Vol. 4, No. 1, pp. 34-51.

Senge, P.M. (1990) The Fifth Discipline: The Art and Practice of the Learning Organisation. Doubleday, New York, NY.

Sedlacik, M., Cechova, I. and Doudova, L. (2013) 'Be born as successful mathematics or language learner: myths, true or 
false?', Journal on Efficiency and Responsibility in Education and Science, Vol. 6, No 3., pp. 155-166. https://doi.org/10.7160/ eriesj.2013.060303

Shahiri, A.M., Husaina, W. and Rashida, N.A. (2015) 'Review on Predicting Student's Performance using Data Mining Techniques', Procedia Computer Science, Vol. 72, pp. 414 - 422. https://doi.org/10.1016/j.procs.2015.12.157

European Association for Quality Assurance in Higher Education (2005) Standards and Guidelines for Quality Assurance in the European Higher Education Area, [online], Available: http:// www.ehea.info/media.ehea.info/file/ENQA/05/3/ENQABergen-Report_579053.pdf [20 May 2018].

Stensaker, B., Langfeldt, L., Harvey, L., Huisman, J. and Westerheijden, D. (2011) 'An in-depth study on the impact of external quality assurance', Assessment \& Evaluation in Higher Education, Vol. 36, No. 4, pp. 465-478. https://doi. org/10.1080/02602930903432074

Sultan, P. and Wong, H.Y. (2013) 'Antecedents and consequences of service quality in a higher education context: a qualitative research approach', Quality Assurance in Education, Vol. 21, No. 1, pp. 70-95. https://doi.org/10.1108/09684881311293070

Tam, M. (2014) 'Outcomes-based approach to quality assessment and curriculum improvement in higher education', Quality
Assurance in Education, Vol. 22, No. 2, pp. 158-168. https://doi. org/10.1108/QAE-09-2011-0059

UNESCO (1998) World Declaration on Higher Education for the Twenty-first Century: Vision and Action. Higher Education in the Twenty-First Century: Vision and Action. [online] http://www. unesco.org/education/educprog/wche/declaration_eng.htm $\quad[15$ May 2018].

Vroeijenstijn, A.I. (1995) Improvement and accountability: Navigating between Scylla and Charybdis. Higher Education Policy Series, 30. London: J. Kingsley Publishers.

Wharrad, H., Chapple, M., and Price, N. (2003). 'Predictors of academic success in bachelor of nursing course'. Nursing Education Today, Vol. 23, No. 4, pp. 54-246. https://doi. org/10.1016/S0260-6917(02)00116-8

Winter. J.C.F. De and Dodou, D. (2011). 'Predicting Academic Performance in Engineering Using High School Exam Scores'. International Journal of Engineering Education. Vol. 27, No. 6, 1343-1351.

Ullrich, D., Pokorny, V. and Ambrozova, E. (2017) 'Leadership, Situational and Systemic Critical Thinking', in Vision 2020: Sustainable Economic development, Innovation Management, and Global Growth. Madrid Spain: International Business Information Management Association (IBIMA), pp. 1323-1332. 